\title{
RNA interference modulates replication of dengue virus in Drosophila melanogaster cells
}

\author{
Swati Mukherjee ${ }^{1}$ and Kathryn A Hanley ${ }^{* 1,2}$
}

\begin{abstract}
Background: Mosquito-borne dengue virus (DENV, genus Flavivirus) has emerged as a major threat to global human health in recent decades, and novel strategies to contain the escalating dengue fever pandemic are urgently needed. RNA interference (RNAi) induced by exogenous small interfering RNAs (siRNAs) has shown promise for treatment of flavivirus infections in hosts and prevention of transmission by vectors. However, the impact of RNAi triggered by authentic virus infection on replication of DENV, or any flavivirus, has received little study. The objectives of the current study were threefold: first, to assess the utility of Drosophila melanogaster S2 cells for the study of DENV, second to investigate the impact of multiple enzymes in the RNAi pathway on DENV replication; and third to test for variation in the response of the four serotypes of DENV to modulation of RNAi.

Results: Three strains from each of the four DENV serotypes showed replication in $\mathrm{S} 2$ cells following infection at multiplicity of infection (MOI) 0.1 and $\mathrm{MOI} 10$; each strain achieved titers $>4.0 \log _{10} \mathrm{pfu} / \mathrm{ml}$ five days after infection at MOI 10. The four serotypes did not differ in mean titer. S2 cells infected with DENV-1, 2, 3 or 4 produced siRNAs, indicating that infection triggered an RNAi response. Knockdown of one of the major enzymes in the RNAi pathway, Dicer-2 (Dcr-2), resulted in a 10 to 100-fold enhancement of replication of all twelve strains of DENV in S2 cells. While serotypes did not differ in their average response to Dcr-2 knockdown, strains within serotypes showed significant differences in their sensitivity to Dcr-2 knockdown. Moreover, knockdown of three additional components of the RNAi pathway, Argonaute 2 (Ago-2), Dcr-1 and Ago-1, also resulted in a significant increase in replication of the two DENV strains tested, and the magnitude of this increase was similar to that resulting from Dcr-2 knockdown.
\end{abstract}

Conclusions: These findings indicate that DENV can replicate in Drosophila S2 cells and that the RNAi pathway plays a role in modulating DENV replication in these cells. S2 cells offer a useful cell culture model for evaluation of the interaction between DENV and the RNAi response.

\section{Background}

The genus Flavivirus contains a large number of emerging, vector-transmitted viruses. Of these, the four serotypes of dengue virus (DENV-1-4) pose the most significant threat to global public health. The global pandemic of dengue fever has escalated dramatically in recent decades, accompanied by a sharp increase in the more severe manifestations of the disease, dengue hemorrhagic fever and dengue shock syndrome [1]. Widespread cessation of vector control, increases in mosquitobreeding sites due to rapid urbanization, and expansion of global travel have all contributed to DENV emergence

* Correspondence: khanley@nmsu.edu

${ }^{1}$ Molecular Biology Program, New Mexico State University, Las Cruces, NM 88003, USA

Full list of author information is available at the end of the article
[2]. Vector control is a costly and often ineffective response to outbreaks [3]. No antivirals are currently available for any flavivirus [4], and although promising DENV vaccine candidates have recently entered clinical trials [5], progress in the development of a DENV vaccine has been slow [6].

In response to this exigency, investigators have pursued novel methods to prevent and treat dengue disease. In particular, there is considerable excitement about the potential to utilize RNA interference (RNAi) (Figure 1) to treat flavivirus infection in the host and control flavivirus transmission by the vector [7]. The RNAi pathway is composed of two major branches (Figure 1). The small interfering RNA (siRNA) branch is triggered by perfectly or nearly-perfectly base-paired exogenous dsRNA and results in RNA degradation, while the cellular microRNA 


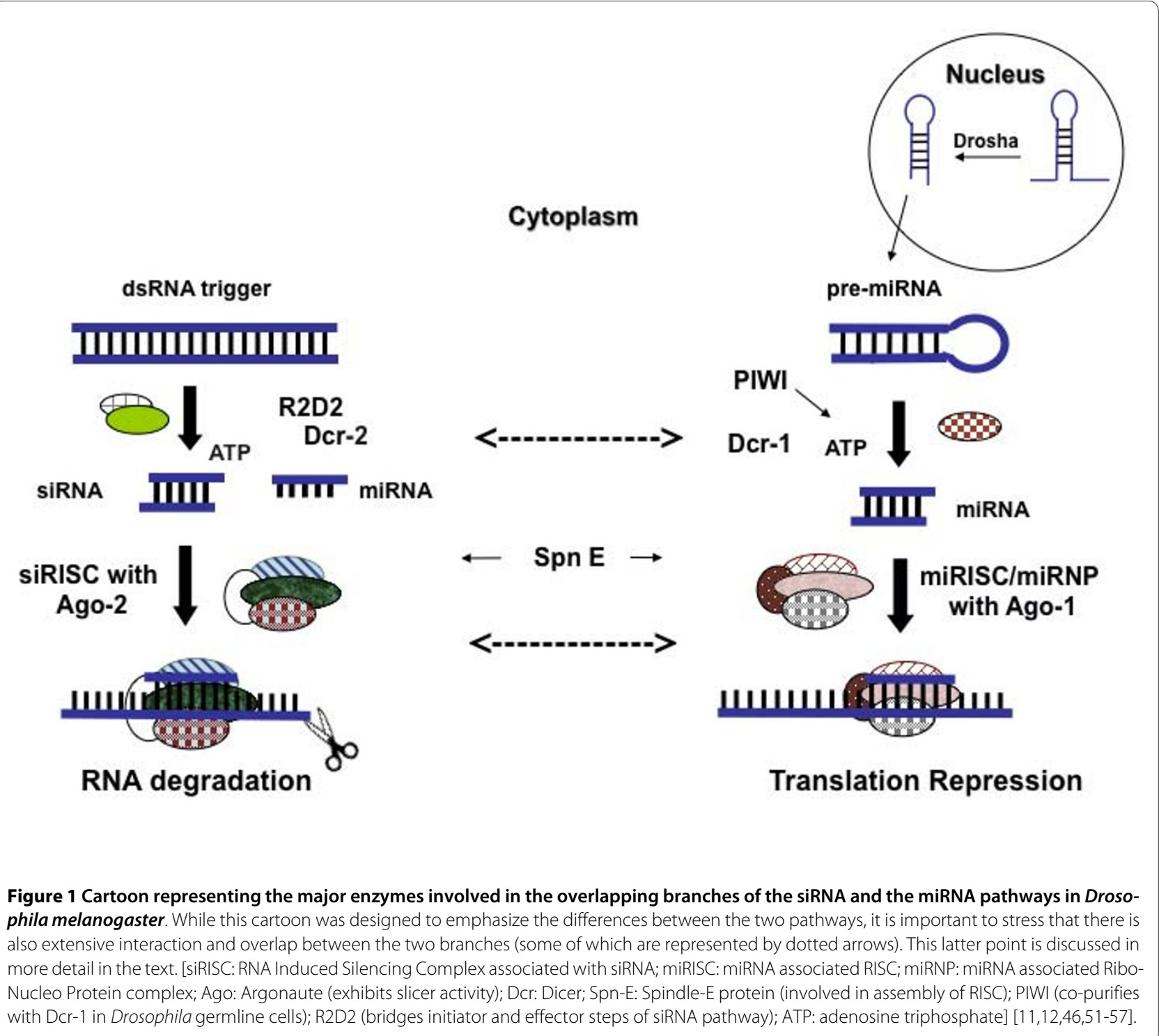

branch (miRNA) is triggered by imperfectly base-paired dsRNA and results in translation repression [8-10]. Although siRNAs and miRNAs are processed via discrete pathways, specific enzymes may participate in both pathways. For example, recent evidence from Drosophila indicates that Dicer (Dcr)-1 is critical for both RNA degradation and translation repression, while Dcr-2 is required only for RNA degradation [11,12], and that Argonaute (Ago)-1 and Ago-2 proteins overlap in their functions [13].

Kumar et al. [14] have demonstrated that introduction of exogenous siRNAs can prevent encephalitis caused by West Nile virus (WNV) and Japanese encephalitis virus infections, and genetically-modified mosquitoes expressing siRNAs are currently being developed to prevent transmission of DENV $[8,15]$. However, the impact of RNAi triggered by endogenous dsRNA produced during virus infection on DENV replication, or that of any flavivirus, has received little study.

To date, only two studies have examined whether virustriggered RNAi regulates replication of a flavivirus. Chotkowski et al. demonstrated that Drosophila melanogaster S2 cells infected with WNV produced abundant antiWNV siRNAs and that knockdown of Ago-2 (Figure 1) in these cells increased the rate but not the overall level of WNV replication [16]. Moreover, D. melanogaster carrying homozygous null mutations in Ago-2, spindle-E (SpnE) or PIWI (Figure 1) supported higher levels of WNV replication than wild type controls, while flies carrying homozygous null mutations in Dcr-2 (Figure 1) did not [16]. Intriguingly, Aedes albopictus mosquito C6/36 cells infected with WNV did not produce anti-WNV siRNA's, prompting the authors to speculate that the RNAi response in this cell line may be weaker than that of Dros- 
ophila cells [16,17]. However Sanchez-Vargas et al. showed that cells of Aedes aegypti mosquitoes, the major vector of DENV, produce anti-DENV siRNA following infection with DENV-2 in culture and in vivo [18]. Moreover in the latter study knockdown of Dcr-2, Ago-2, or R2D2 (Figure 1) all significantly enhanced the rate and level of DENV-2 replication, with knockdown of Dcr-2 having the strongest impact. These findings indicate that components of both the miRNA and the siRNA branches are involved in modulating viral replication, and that complete functional segregation of the two branches is lacking.

To gain further insight into the ability of RNAi to modulate DENV infection, in the current study we first investigated whether S2 cells are susceptible to DENV infection. S2 cells are an attractive substrate for investigation of RNAi for three reasons: (i) the RNAi pathway in Drosophila is well characterized, (ii) RNAi knockdown in S2 cells can be accomplished simply be overlaying them with dsRNA or siRNA [19], and (iii) previously validated siRNA's for knockdown of specific RNAi enzymes are readily available $[20,21]$. After finding that DENV replicates in S2 cells, we tested whether S2 cells respond to DENV infection by production of siRNA. Finally, we tested the impact of individually knocking down four enzymes of the RNAi pathway: Dcr-1, Dcr-2, Ago-1 and Ago-2 on the replication dynamics of DENV.

\section{Methods \\ Cells}

Schneider S2 cells (Drosophila melanogaster embryonic cells) [22] acquired from the Drosophila Genomics Resource Center (Bloomington, IN) were maintained at $28^{\circ} \mathrm{C}$ in conditioned S2 media composed of Schneider's Drosophila media (Invitrogen, Carlsbad, CA) supplemented with 10\% Fetal Bovine Serum (FBS, Invitrogen), 1 $\mathrm{mM}$ L-glutamine (Invitrogen), and $1 \times$ Penicillin-Streptomycin-Fungizone (PSF, Invitrogen). Media used for dsRNA/siRNA dilutions (unconditioned S2 media) was Schneider's Drosophila media supplemented with $1 \mathrm{mM}$ L-glutamine and $1 \times$ PSF. C6/36 cells (Ae. albopictus epithelial cells) [23] were maintained at $32^{\circ} \mathrm{C}$ with $5 \% \mathrm{CO}_{2}$ in minimal essential media (MEM, Invitrogen) supplemented with $10 \% \mathrm{FBS}, 2 \mathrm{mM}$ L-glutamine, $2 \mathrm{mM}$ nonessential amino acids (Invitrogen) and $0.05 \mathrm{mg} / \mathrm{ml}$ gentamycin (Invitrogen).

\section{Viruses}

To compare the replication of the four serotypes of DENV, three isolates of each were selected from a broad array of geographical locations (Table 1). Each isolate was passaged in $\mathrm{C6} / 36$ cells to generate a stock, designated C6/36 p1 MOI 0.1, for use in all experiments. C6/36 cells were infected at MOI 0.1, incubated for two hrs with occasional, gentle rocking under the conditions described above. Five days post infection (pi), supernatant was collected, clarified by centrifugation, stabilized with 0.1 times volume of $10 \times$ SPG $(2.18 \mathrm{mM}$ sucrose, $60 \mathrm{mM} \mathrm{L}$ glutamic acid, $38 \mathrm{mM}$ potassium phosphate [monobasic], $72 \mathrm{mM}$ potassium phosphate [dibasic]), and stored at $80^{\circ} \mathrm{C}$. The titer of each $\mathrm{C} 6 / 36 \mathrm{p} 1 \mathrm{MOI} 0.1$ stock was determined via serial titration in $\mathrm{C} 6 / 36$ cells as described below.

\section{Quantification of virus titer}

Monolayers of $\mathrm{C} 6 / 36$ cells were grown to $80 \%$ confluency in 24-well tissue culture treated plates (BD Falcon, Franklin Lakes, NJ) and infected with serial tenfold dilutions of each stock virus or cell supernatant. Plates were incubated for two hrs with intermittent gentle rocking at $32^{\circ} \mathrm{C}$. Inoculated monolayers were overlaid with $0.8 \%$ methylcellulose in OptiMEM (Invitrogen) supplemented with $2 \% \mathrm{FBS}, 2 \mathrm{mM} \mathrm{L}$-glutamine and $0.05 \mathrm{mg} / \mathrm{ml}$ gentamycin. Focus forming units are referred to as "plaques" hereafter for consistency with previous literature [24-28]; plaques were detected via immunostaining as previously described [29]. DENV-1 - 4 were detected using DENV 1 specific monoclonal antibody $15 \mathrm{~F} 3$, DENV - 2 hyperimmune mouse ascites fluid (HMAF), DENV - 3 specific hybridoma cell supernatant, and DENV- 4 HMAF, respectively; all antibodies were the kind gift of Dr. Stephen S. Whitehead, National Institute of Allergy and Infectious Disease, National Institutes of Health, Bethesda, MD.

\section{Infection of $\mathrm{S} 2$ cells by DENV}

S2 cells were grown to $80 \%$ confluency $\left(6.0 \log _{10}\right.$ cells/well $\pm 3.1 \log _{10}$ cells/well) in six-well tissue culture treated plates (BD Falcon). Triplicate wells were infected with each of the $12 \mathrm{C} 6 / 36 \mathrm{p} 1 \mathrm{MOI} 0.1$ stocks at a specified MOI, based on titer in C6/36 cells (Table 1) divided by the number of S2 cells/well, in a total volume of one $\mathrm{ml}$. Virus was incubated for two hrs at $28^{\circ} \mathrm{C}$ with occasional, gentle rocking and washed once with one $\mathrm{ml}$ of conditioned S2 media. Thereafter three $\mathrm{ml}$ of conditioned S2 media was added to each well. S2 cells were infected at MOI 10 and incubated for five days at $28^{\circ} \mathrm{C}$ after which cell supernatants, designated S2 p1 MOI 10, were collected and frozen as described above. $500 \mu \mathrm{l}$ from each S2 p1 MOI 10 replicate were then passaged in fresh S2 cells as described above. Given the titers on day five for S2 p1 MOI 10 (Figure 2A), $500 \mu \mathrm{l}$ of supernatants contained a total of $3.2-4.4 \log _{10}$ plaque forming units $\left(\log _{10} \mathrm{pfu}\right)$. Cells were incubated for five days and harvested to yield S2 p2 MOI 10. S2 cells were infected similarly at MOI 0.1 to yield cell supernatants $\mathrm{S} 2 \mathrm{p} 1 \mathrm{MOI} 0.1$, but these supernatants were not passaged further. Virus titer in all cell supernatants was determined by serial titration in $\mathrm{C} 6 / 36$ cells as described above. 
Table 1: Passage history and titer (in C6/36 cells) of the 12 dengue virus strains used in this study

\begin{tabular}{|c|c|c|c|c|c|c|c|}
\hline Serotype & Strain ID & $\begin{array}{l}\text { Country of } \\
\text { isolation }\end{array}$ & Source & $\begin{array}{l}\text { Collection } \\
\text { Year }\end{array}$ & Passage History1 & $\begin{array}{l}\text { Titer }\left(\log _{10}\right. \\
\text { pfu/ml) }\end{array}$ & $\begin{array}{l}\text { Obtained } \\
\text { from2 }\end{array}$ \\
\hline DENV-1 & JKT 85-1415 & Indonesia & Human serum & 1985 & $\mathrm{C} 6 / 36 \mathrm{p} 2$ & 7.2 & WRCEVA \\
\hline DENV-1 & 1335 TVP & Sri Lanka & Human serum & 1981 & $\begin{array}{l}\text { Inoculated mosquito- } 1 \mathrm{X} \\
\mathrm{C} 6 / 36 \mathrm{p} 2\end{array}$ & 7.2 & WRCEVA \\
\hline DENV-1 & AusHT15 & Australia & Human serum & 1983 & $\mathrm{C} 6 / 36 \mathrm{p} 2$ & 7.5 & WRCEVA \\
\hline DENV-2 & Tonga/1974 & Tonga & Human serum & 1974 & Mosquito-1X, C6/36 p5 & 8.0 & NIAID \\
\hline DENV-2 & DOO-0372 & Thailand & Human serum & 1988 & $\begin{array}{l}\text { Previous history unknown, } \\
\mathrm{C} 6 / 36 \mathrm{p} 8\end{array}$ & 8.0 & NIAID \\
\hline DENV-2 & NGC Proto & New Guinea & Human serum & 1944 & Inoculated monkey- $1 \mathrm{X}$ & 7.5 & NIAID \\
\hline DENV-3 & $\begin{array}{l}89 \text { SriLan } \\
\text { 1: D2783 }\end{array}$ & Sri Lanka & Human serum & 1989 & $\mathrm{C} 6 / 36 \mathrm{p} 2$ & 7.6 & UNC \\
\hline DENV-3 & 89 SriLan 2: D1306 & Sri Lanka & Human serum & 1983 & $\mathrm{C} 6 / 36 \mathrm{p} 2$ & 7.6 & UNC \\
\hline DENV-3 & Sleman/78 & $\begin{array}{l}\text { Indonesia } \\
\text { (Java) }\end{array}$ & Human serum & 1978 & $\begin{array}{l}\text { Mosquito-1X, Vero p2, C6/ } \\
36 \text { p4 }\end{array}$ & 7.2 & NIAID \\
\hline DENV-4 & 1228 TVP & Indonesia & Human serum & 1978 & Mosquito p2, C6/36 p2 & 7.1 & WRCEVA \\
\hline DENV-4 & 779157 & Taiwan & Human serum & 1988 & $\mathrm{C} 6 / 36 \mathrm{p} 5$ & 7.4 & WRCEVA \\
\hline DENV-4 & BeH 403714 & Brazil & Human serum & 1982 & C6/36 p3 & 7.2 & WRCEVA \\
\hline
\end{tabular}

${ }^{1}$ cell type for passage followed by total number of passages $(p)$ in that cell type

2 WRCEVA: provided by Dr. Robert Tesh at the World Reference Center of Emerging Viruses and Arboviruses at the University of Texas at Galveston (UTMB); NIAID: provided by Dr. Stephen Whitehead, NIAID, NIH; UNC: provided by Dr. Aravinda de Silva, Department of Microbiology and Immunology, University of North Carolina.

\section{DENV replication kinetics in S2 cells}

Triplicate wells of S2 cells in six-well plates were infected with the C6/36 p1 MOI 0.1 stock of DENV-4 Taiwan at MOI 0.1. Two hrs post infection the inoculum was removed, cells were washed once with conditioned S2 media, fresh media was added and $1 \mathrm{ml}$ cell supernatant was collected from each well 2, 24, 48, 72, 96 and $120 \mathrm{hrs}$ pi and frozen as described above. Fresh media was added to each well for every sampling point so that the total volume of media remained constant.

\section{Detection of anti-DENV siRNAs in S2 cells}

Northern blots were used to detect anti-DENV siRNAs in infected S2 cells. To assess the production of siRNA's in response to infection, one set of $\mathrm{S} 2$ cells at $80 \%$ confluency were infected with DENV-1 JKT, DENV-2 Tonga,
DENV-3 Sleman and DENV-4 Taiwan at MOI 0.1 as described above. To assess the impact of knocking down components of the RNAi pathway on siRNA production, a second, concurrent set of S2 cells were treated with dsRNA to Dcr-1 or Dcr-2 and then infected with DENV-1 JKT, DENV-2 Tonga, DENV-3 Sleman and DENV-4 Taiwan as described below. Three days pi small RNAs (15 100 nucleotides) were isolated using mirPremier ${ }^{\circ}$ microRNA Isolation kit (Sigma Aldrich, St. Louis, MO). RNA was quantified, separated on $15 \%$ urea polyacrylamide gel using Tris Borate EDTA and transferred to Hybond $^{\mathrm{Tm}}-\mathrm{N}+$ nylon membrane (Amersham Biosciences, Pittsburgh, PA). Blots were probed with approximately 400 nucleotide long digoxigenin (DIG) labeled positivesense probes complementary to nucleotides 10271 10735 of the 3 ' untranslated region (UTR) of DENV-1 


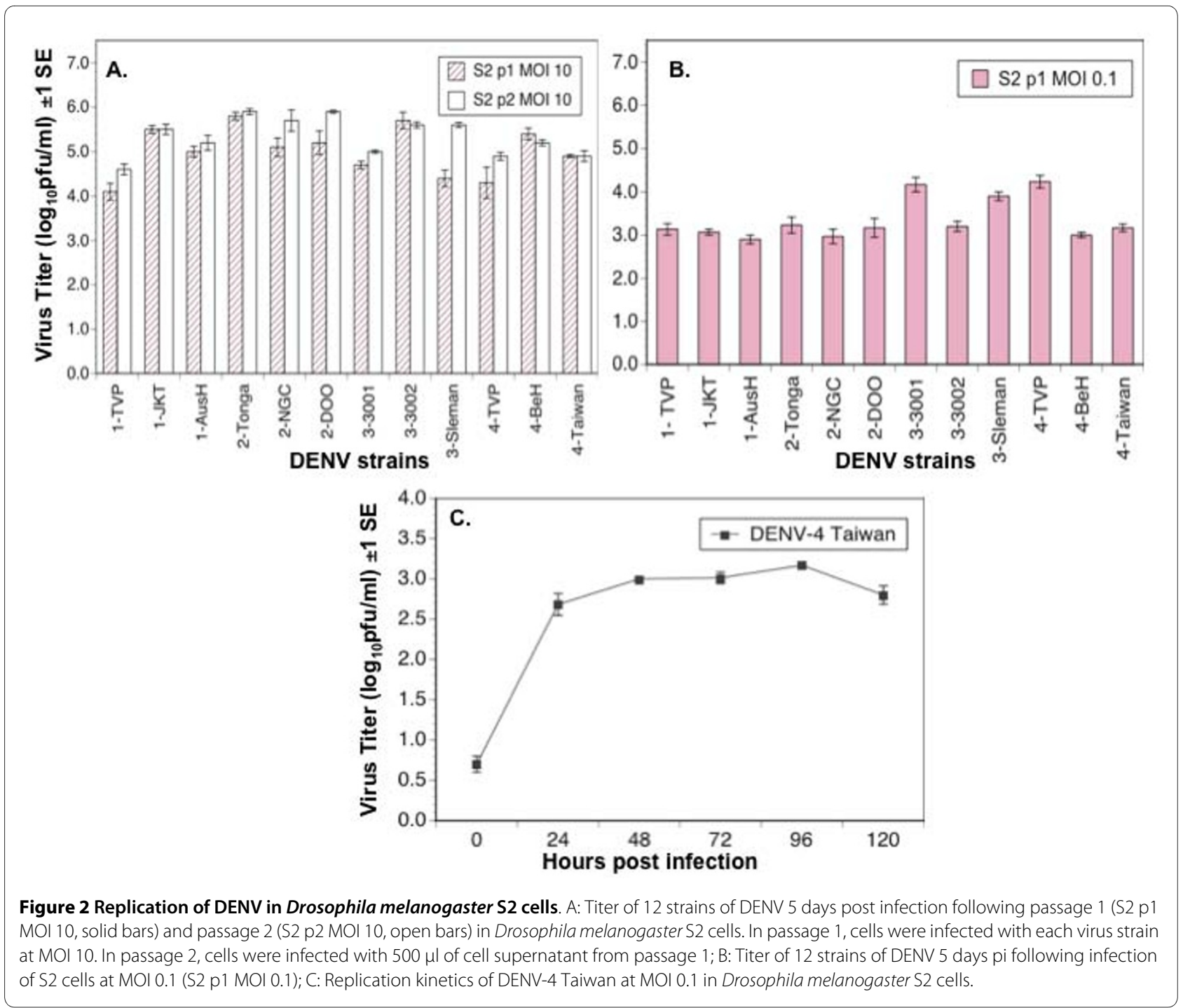

Western Pacific, 10270 - 10713 of the 3'UTR of DENV-2 Tonga, 10243 - 10686 of the 3'UTR of DENV-3 Sleman and 10240 - 10645 of the 3'UTR of DENV-4 Taiwan. The justification for targeting the probe to the 3' UTR is based on a recent report that anti-West Nile virus siRNA's cluster, among other genome locations, in the 3' UTR [30]. Blots were processed according to protocol defined by the manufacturer for DIG probes (Roche Diagonistics, Indianapolis, IN).

\section{Knockdown of enzymes in the RNAi pathway}

Four components of the RNAi pathway, Ago-1, Ago-2, Dcr-1 and Dcr-2 (Figure 1) were separately depleted using 500 base-pair (bp) dsRNA targeting nucleotides 140 - 641 of Dcr-1, 763 - 1264 of Dcr-2, 1151 - 1651 of Ago-1 mRNA from D. melanogaster [Genbank: NM 079729, NM 079054, DQ398918 respectively] or a previously validated $22 \mathrm{bp}$ siRNA against $D$. melanogaster Ago-2 [20]. A dsRNA targeting nucleotides 72 - 573 of
pGEX-2T cloning vector (GE Healthcare Life Sciences, Piscataway, NJ) was used as a control for dsRNA knockdown while a Renilla luciferase siRNA (Ambion, Austin, TX) targeting luciferase was used as control for siRNA knockdown. To generate dsRNA, D. melanogaster DNA was isolated using the Qiagen DNeasy Blood \& Tissue Kit (Qiagen, Valencia, CA, USA) and amplified using primers specific to D. melanogaster Ago-1, Ago-2, Dcr-1 and Dcr2 (Table 2). Primers contained a T7 promoter sequence at the $5^{\prime}$ end to allow for transcription using MEGAscript ${ }^{\circ}$ RNAi Kit (Ambion) according to manufacturer's instruction. Transcription of siRNA was performed using Silencer ${ }^{\circ}$ siRNA construction kit (Ambion). $6.0 \log _{10} \pm 3.0$ $\log _{10} \mathrm{~S} 2$ cells were plated on six-well plates and incubated for 20 minutes at $28^{\circ} \mathrm{C}$. dsRNA/siRNA were diluted in one $\mathrm{ml}$ of unconditioned S2 media to $100 \mathrm{nM}$, applied to the $\mathrm{S} 2$ cells, and incubated at $28^{\circ} \mathrm{C}$ for $16 \mathrm{hrs}$. Thereafter three $\mathrm{ml}$ of conditioned S2 media was added and cells 
were incubated as described above [31]. Cells were re-fed with dsRNA/siRNA three days following initial treatment.

\section{Verification of Knockdown}

To assess the efficacy of knockdown, seven wells of S2 cells were treated with each of the dsRNA/siRNA's described above. At two hrs, 24 hrs, and daily thereafter through day six post-treatment, cells from one well corresponding to each dsRNA/siRNA treatment were lysed using RIPA buffer (Thermo Scientific, Waltham, MA) and centrifuged for 25 minutes at $10,000 \mathrm{rpm}$ at $4^{\circ} \mathrm{C}$. Supernatants were stored at $-80^{\circ} \mathrm{C}$ in order to analyze all samples concurrently. Total protein in each sample was quantified using BCA Protein Assay kit (Pierce, Rockford, IL). Supernatants were separated on a polyacrylamide gel and transferred to Immobilon polyvinylidene fluoride transfer membranes (Millipore, Billerica, MA). Membranes were blocked with bovine serum albumin and incubated with $D$. melanogaster specific anti-Dcr-1 (Catalog number: ab52680), anti-Dcr-2 (Catalog number: ab4732), anti-Ago-1 (Catalog number: ab5070), or antiAgo-2 antibody (Catalog number: ab5072) (Abcam, Cambridge, MA) as appropriate. Protein bands were visualized with secondary anti-rabbit or anti-mouse HRPconjugated IgG (Kirkegaard and Perry Laboratories, Gaithersburg, MD) using the ECL system (GE Healthcare).

\section{Toxicity assay}

To assess whether knockdown of Dcr-1, Dcr-2, Ago-1 or Ago-2 affected the viability of $\mathrm{S} 2$ cells, a resazurin-based viability assay was performed. S2 cells were propagated to $80 \%$ confluency in five 96 well tissue culture treated plates (Costar, Lowell, MA). Each treatment was performed in triplicate wells on each plate as follows. Media was removed and designated dsRNA/siRNA's were added at a concentration of $100 \mathrm{nM}$. Two controls were included in the assay: treatment with $100 \mu \mathrm{l}$ of conditioned S2 media was used to measure overall cell viability and treatment with $8 \%$ DMSO was used to measure the impact of a compound known to be toxic. Plates were incubated for one to five days; on each day $100 \mu \mathrm{l}$ of resazurin from the In Vitro Toxicology Assay Kit (Sigma-Aldrich, St. Louis, MO) was added all the wells of one plate. The plate was then incubated two hrs and absorbance was read on a plate reader (TiterTek, Huntsville, AL) at $600 \mathrm{~nm}$. The proportion of viable cells was determined by dividing the absorbance of each well on the plate by the average absorbance of the media-treated wells.

\section{DENV infection following knockdown of Dcr-2}

For each of the C6/36 p1 MOI 0.1 stocks of 12 DENV strains (Table 1), triplicate wells of S2 cells in six-well plates were treated with dsRNA targeting Dcr-2 or with control dsRNA as described above. Sixteen hrs post treatment wells were infected with the designated virus strain at MOI 10 and incubated at $28^{\circ} \mathrm{C}$. Based on the results of knockdown verification (below), infected cells were replenished with dsRNA $72 \mathrm{hrs}$ pi. Cell supernatants were carefully removed and stored in individual tubes at room temperature, leaving one $\mathrm{ml}$ residual supernatant per well. $100 \mathrm{nM}$ dsRNA was added to each well and incubated for 30 minutes at $28^{\circ} \mathrm{C}$. Each cell supernatant that

Table 2: Primers used for amplification of targets for dsRNA generation

\begin{tabular}{llc}
\hline Primer Name & Primer sequence1 & Protein \\
\hline Dicer-1-Forward & CTAATACGACTCACTATAGGGCGGAACACGATTATTTGCCTGGG & Dicer-1 \\
\hline Dicer-1 Reverse & CTAATACGACTCACTATAGGGCGCAACACGGTGACAATATCACTG & Dicer-1 \\
\hline Dicer-2 Forward & CTAATACGACTCACTATAGGGAAGAGCAAGTGCTCACGGTTACAAG & Dicer-2 \\
\hline Dicer-2 Reverse & CTAATACGACTCACTATAGGGGCGTAGACTGGATGTAGTTGAGCA & Dicer-2 \\
\hline Argonaute-2 Forward & CTAATACGACTCACTATAGGGCATCAACTATCTGGACCTTGACCTG & Argonaute-2 \\
\hline Argonaute-2 Reverse & CTAATACGACTCACTATAGGGAAACAACCTCCACGCACTGCATTG & Argonaute-2 \\
\hline dsRNAControl-Forward & CTAATACGACTCACTATAGGGCAGGTCGTAAATCACTGCATAATTC & Control \\
\hline dsRNAControl-Reverse & CTAATACGACTCACTATAGGGCACCGTATCTAATATCCAAAACCG & Control
\end{tabular}


was removed was added back to its original well containing one $\mathrm{ml}$ of residual media. Cell supernatants were harvested $120 \mathrm{hrs}$ pi and virus titer was determined as described above.

\section{DENV replication kinetics following knockdown of Dcr-1, Dcr-2, Ago-1 or Ago-2}

To monitor the impact of RNAi knockdown on DENV replication kinetics, sets of six wells of S2 cells in six-well plates were treated with one dsRNA/siRNA targeting Dcr-1, Dcr-2, Ago-1, Ago-2 or one control dsRNA/ siRNA, as described above. 16 hrs post treatment, three wells treated with each enzyme were infected with DENV-4 Taiwan and three with DENV-2 Tonga at MOI 10. One ml cell supernatant was collected from each well 2, 24, 48, 72, 96 and $120 \mathrm{hrs}$ pi and frozen as described above; one $\mathrm{ml}$ of fresh media was then added to each well so that the total volume of media remained constant. All wells were re-fed dsRNA/siRNA at $72 \mathrm{hrs}$ pi as described above.

\section{Statistical Analysis}

All statistical analyses were carried out using Statview (SAS Institute, Cary, NC).

\section{Results}

\section{Infection of $\mathrm{S} 2$ cells by DENV}

Every DENV strain achieved a titer $>7.0 \log _{10} \mathrm{pfu} / \mathrm{ml}$ in C6/36 cells five days post-infection at MOI 0.1 (Table 1). Five days after infection of S2 cells at MOI 10, the 12 DENV strains reached titers ranging from 4.1 to $5.9 \log _{10}$ $\mathrm{pfu} / \mathrm{ml}$ (Figure 2A). There was a significant positive correlation between titer of the 12 DENV strains in C6/36 (C6/36 p1 MOI 0.1) with the titer of those strains in S2 $(\mathrm{S} 2 \mathrm{p} 1 \mathrm{MOI} 10)(\mathrm{r}=0.62, \mathrm{P}=0.03)$. There was no significant difference among the four DENV serotypes in titer following this first passage in S2 cells (ANOVA, $\mathrm{df}=3, \mathrm{~F}$ $=2.54, \mathrm{P}=0.13$ ), and titer did not change significantly following a second passage in S2 cells, S2 p2 MOI 10 (Figure $2 \mathrm{~A}$; paired t-test, $\mathrm{df}=11, \mathrm{P}=0.66$ ).

To confirm that the titers observed in S2 cells resulted from virus replication rather than carry-over of the inoculum, S2 cells were also infected with all 12 strains of DENV at MOI 0.1; five days pi all 12 strains had achieved titers ranging from 2.9 to $4.2 \log _{10} \mathrm{pfu} / \mathrm{ml}$ (Figure 2B). There was no significant correlation between titers of the 12 strains following infection of S2 cells at MOI 0.1 (S2 p1 MOI 0.1) and MOI 10 (S2 p1 MOI 10) $(\mathrm{r}=-0.55, \mathrm{P}=$ $0.06)$ or between titers of the 12 strains following infection of S2 cells at MOI 0.1 (S2 p1 MOI 0.1) and C6/36 cells at MOI 0.1 (C6/36 p1 MOI 0.1) $(\mathrm{r}=-0.19, \mathrm{P}=0.54)$. Additionally the replication kinetics of one strain, DENV4 Taiwan, were followed daily for five days (Figure 2C); there was significant difference in virus titer among days post-infection (repeated measures ANOVA, $\mathrm{df}=5, \mathrm{~F}=$ 113.09, P < 0.0001); specifically, a Tukey-Kramer posthoc test revealed that virus titer increased between two hrs and 24 hrs $(\mathrm{P}<0.5)$ and leveled off thereafter at approximately $3.0 \log _{10} \mathrm{pfu} / \mathrm{ml}$.

\section{Detection of anti-DENV siRNA in S2 cells}

Virus-derived small RNAs can range from 18 - 30 nucleotides depending on secondary structure of the viral genome and processing by RNA processing enzymes $[16,32]$. Virus derived small RNAs were detected in S2 cells three days after infection with DENV-1 TVP, DENV2 Tonga, DENV-3 Sleman and DENV-4 Taiwan by Northern blotting (Figure 3) using positive-sense probes designed to detect negative sense siRNAs that targeted the positive sense genome of each respective serotype. No virus-derived siRNA's were detected in uninfected control cells. Knockdown of Dcr-1 or Dcr-2 resulted in a substantial decrease in the production of virus-derived siRNA's in S2 cells infected with each of the four isolates above (Figure 3). The most extreme effect was apparent for Dcr-2 knockdown followed by infection with DENV-4 Taiwan; in this treatment no virus-derived siRNA's were detected at all (Figure 3D, compare lane 3 to lane 1).

\section{Toxicity in S2 cells following knockdown of Dcr-1, Dcr-2, Ago-1 or Ago-2}

Knockdown of each of the four components of the RNAi pathway had no significant effect on cell viability (Figure 4). A two-factor ANOVA testing the effect of treatment and day post-infection on absorbance revealed a significant effect of treatment $(\mathrm{df}=5, \mathrm{~F}=88.0, \mathrm{P}<0.001)$ but not day $(\mathrm{df}=4, \mathrm{~F}=0.2, \mathrm{P}=0.91)$. However a TukeyKramer post-hoc test revealed that only the DMSOtreated cells, which were expected to show reduced viability, differed significantly from control cells $(\mathrm{P}<0.05)$, while none of the dsRNA/siRNA treated cells differed from controls $(\mathrm{P}>0.05)$.

\section{DENV replication following knockdown of RNAi genes}

To test whether the RNAi response has an effect on DENV replication in S2 cells, four components of the RNAi pathway (Dcr-1, Dcr-2, Ago-1 and Ago-2) were individually depleted via knockdown with an appropriate dsRNA or siRNA. The efficacy of depletion of each enzyme was confirmed using Western blot analysis (Figure 5). Dcr-1 levels were depleted for six days following treatment, but unlike the other three treatments there were no days on which Dcr-1 expression was undetectable. Dcr-2 expression was undetectable until day three post-treatment and showed steady recuperation thereafter. Ago-1 expression was undetectable through day five post-treatment. Ago-2 expression was undetectable until day three post-treatment and rebounded on day four. To 

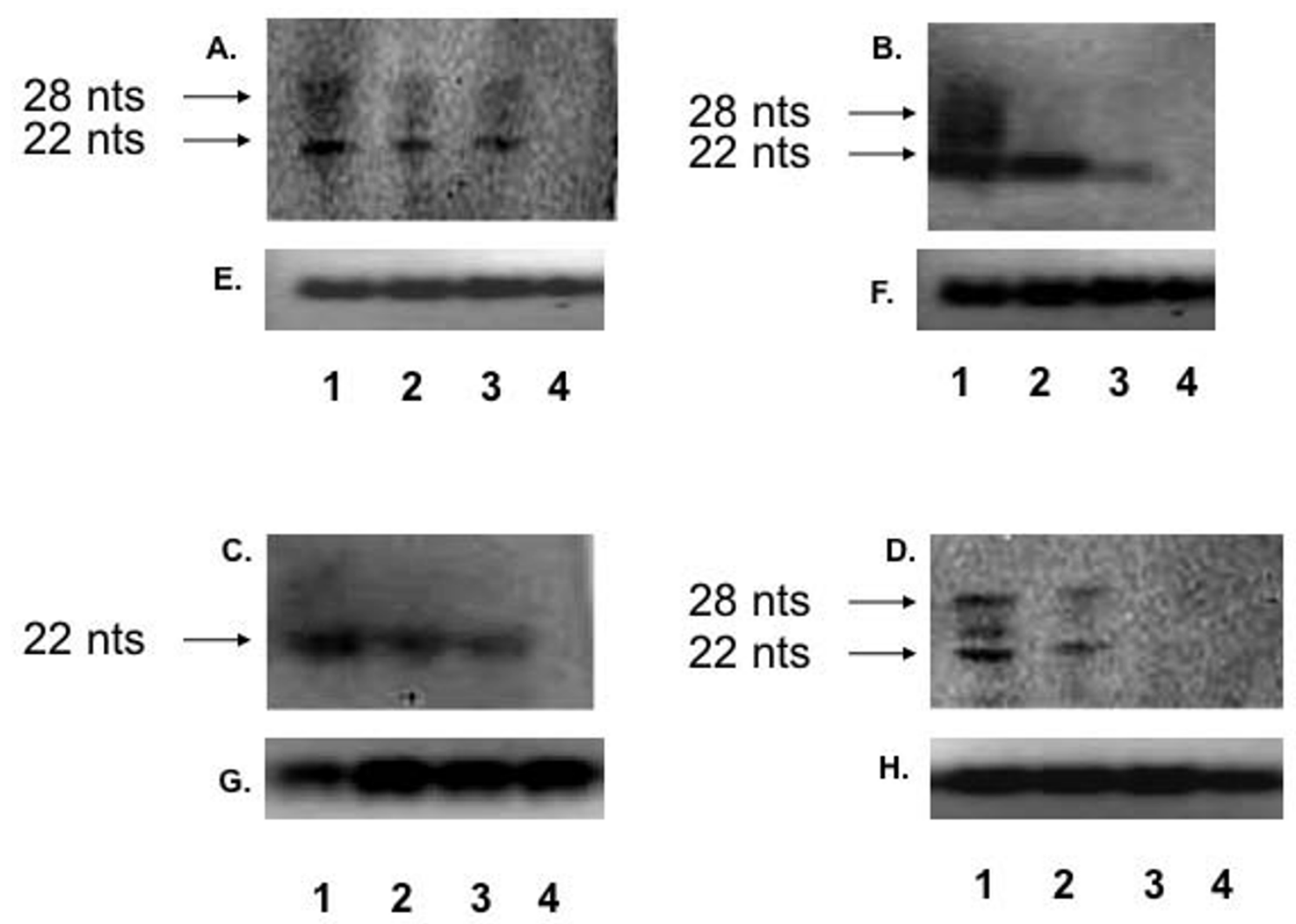

Figure 3 Detection of siRNAs in S2 cells infected with specified DENV strain (Lane 1), specified DENV strain following Dcr-1 knockdown (Lane 2), specified DENV strain following Dcr-2 knockdown (Lane 3), or uninfected cells (Lane 4) by Northern blot probed with DENV 3 'UTR specific probe. A- DENV-1 TVP. B- DENV-2 Tonga. C-DENV-3 Sleman. D-DENV-4 Taiwan. E-H:Total RNA loaded for A, B, Cand D, stained with ethidium bromide, as an equal loading control.

prevent recovery of expression, all infected cell knockdowns were re-fed dsRNA/siRNA on day three post initial dsRNA/siRNA treatment.

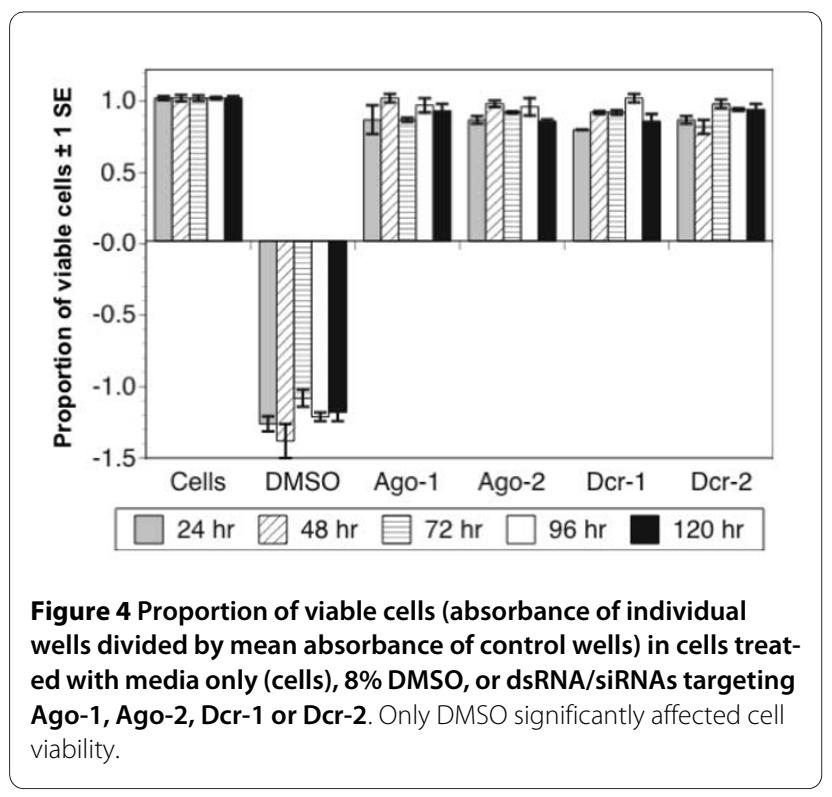

As shown in Figure 6, all 12 DENV strains tested achieved significantly higher titers (usually a 100-fold increase) in cells depleted of Dcr-2 relative to control cells (paired t-test, $\mathrm{df}=11, \mathrm{P}<0.0001$ ). The $12 \mathrm{DENV}$ strains attained similar titers in cells treated with a control dsRNA treatment as compared to untreated cells. Moreover, there was no significant difference among serotypes in the impact of Dcr-2 knockdown, measured as the difference in titer for a particular replicate virus in knockdown cells versus control cells (ANOVA, $\mathrm{df}=3, \mathrm{~F}=1.04$, $\mathrm{P}=0.41$ ). In contrast, variation in the impact of RNAi knockdown on the three DENV strains within serotypes was detected using factorial ANOVAs for each serotype; when significant differences were detected, a TukeyKramer post-hoc test was used to determine which strains showed significant differences in response to knockdown. DENV-1 strains showed significant variation in response to Dcr-2 knockdown $(\mathrm{df}=3, \mathrm{~F}=9.81, \mathrm{P}=$ 0.048): strain TVP showed a significantly greater increase in titer when Dcr-2 was knocked down than strains JKT and AusH; the latter two did not differ from each other. DENV-2 and DENV-3 strains did not show significant 


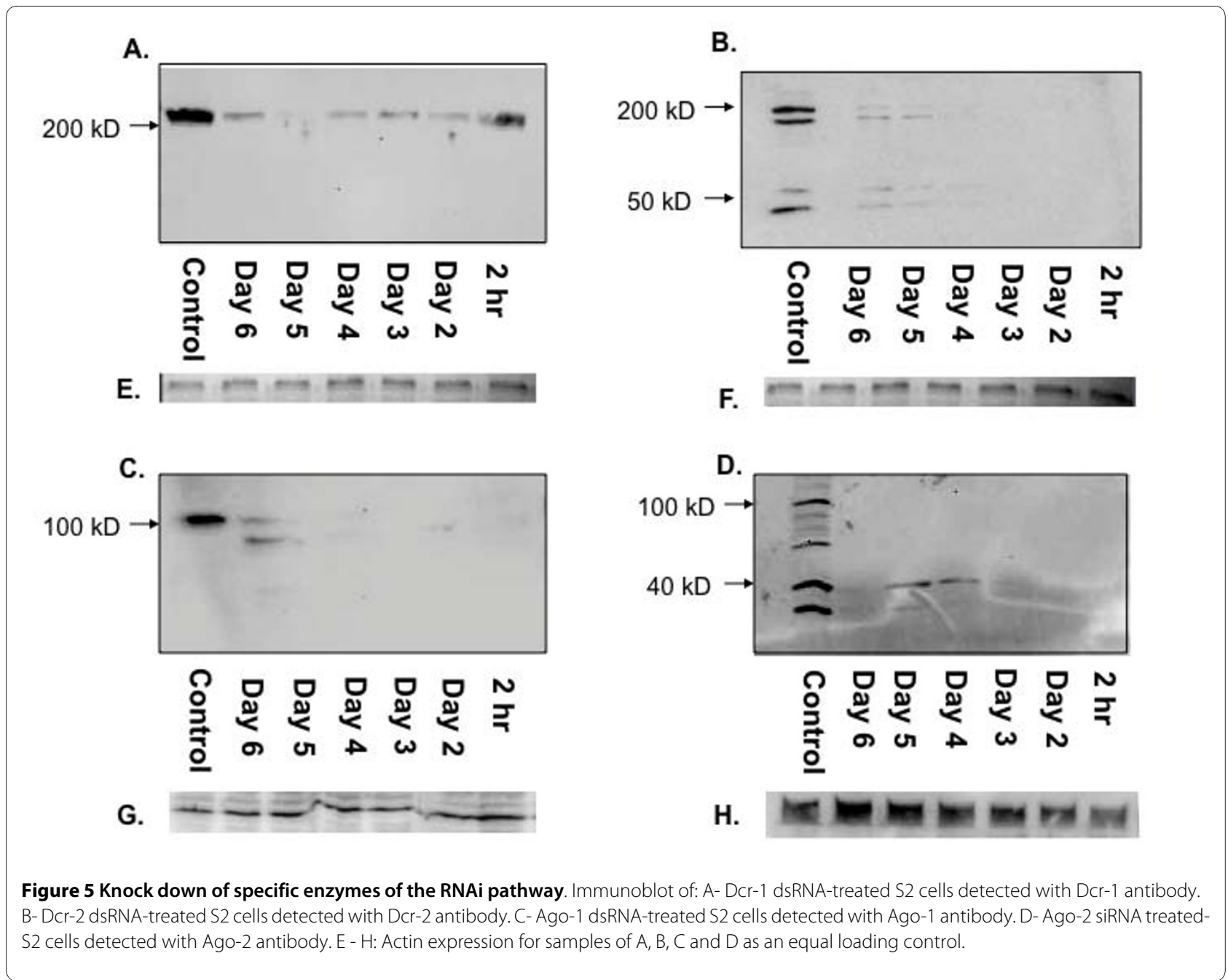

within-serotype variation $(\mathrm{DENV}-2 \mathrm{df}=2, \mathrm{~F}=2.24, \mathrm{P}=$ 0.19; DENV-3 df $=2, \mathrm{~F}=4.82=, \mathrm{P}=0.06)$. DENV-4 strains also showed significant variation to Dcr-2 knockdown $(\mathrm{df}=3, \mathrm{~F}=9.8, \mathrm{P}=0.048)$ : all three strains tested differed significantly from each other.

Subsequent analyses focused on two DENV strains that had shown the smallest (DENV-2 Tonga) and an intermediate (DENV-4 Taiwan) response to Dcr-2 knockdown (Figure 6). A multistep growth curve revealed that knockdown of Dcr-2 resulted in enhancement of replication of both strains within $48 \mathrm{hrs}$ pi, and by $72 \mathrm{hrs}$ pi both strains had achieved a titer 10 - 100 - fold higher in Dcr-2 depleted cells than control cells (Figures 7 and 8). A similar pattern was observed following knockdown of Dcr-1, Ago-1 and Ago-2 (Figures 7 and 8); titers of both DENV strains were significantly higher in cells depleted of each enzyme than control cells $96 \mathrm{hrs}$ pi (unpaired t-tests; $\mathrm{df}=$ $4, \mathrm{P}<0.02$ for all comparisons).

\section{Discussion}

The objectives of this study were threefold: first, to monitor the pattern of replication of DENV in S2 cells in order to assess the utility of S2's for the study of DENV, second to investigate the impact of RNAi on DENV replication; and third to test whether the impact of RNAi differs among the four serotypes of DENV.

Five lines of evidence demonstrate that all four DENV serotypes replicated in S2 cells. First, infection of S2 cells with DENV at an MOI 10 and MOI 0.1 resulted in titers > 4.1 and $>2.9 \log _{10} \mathrm{pfu} / \mathrm{ml}$, respectively, even though the input virus inoculum was thoroughly washed away two hours post-infection. Second, titers attained by DENV following a second passage in S2 cells $\left(4.2-5.9 \log _{10} \mathrm{pfu} /\right.$ $\mathrm{ml}$ ) were substantially larger than the total amount of virus used to initiate infection $\left(3.2-4.4 \log _{10} \mathrm{pfu}\right)$. Third, daily monitoring of the titer of DENV-4 Taiwan in S2 cells showed that titers increased significantly following one day of infection. Fourth, siRNAs were detected in S2 cells after infection with each of the four serotypes of DENV, indicating that DENV infects and replicates in S2 cells. Finally, a significant increase in titer was observed for all DENV strains when Dcr-2 was knocked down using dsRNAs. Such change in titer following down regu- 


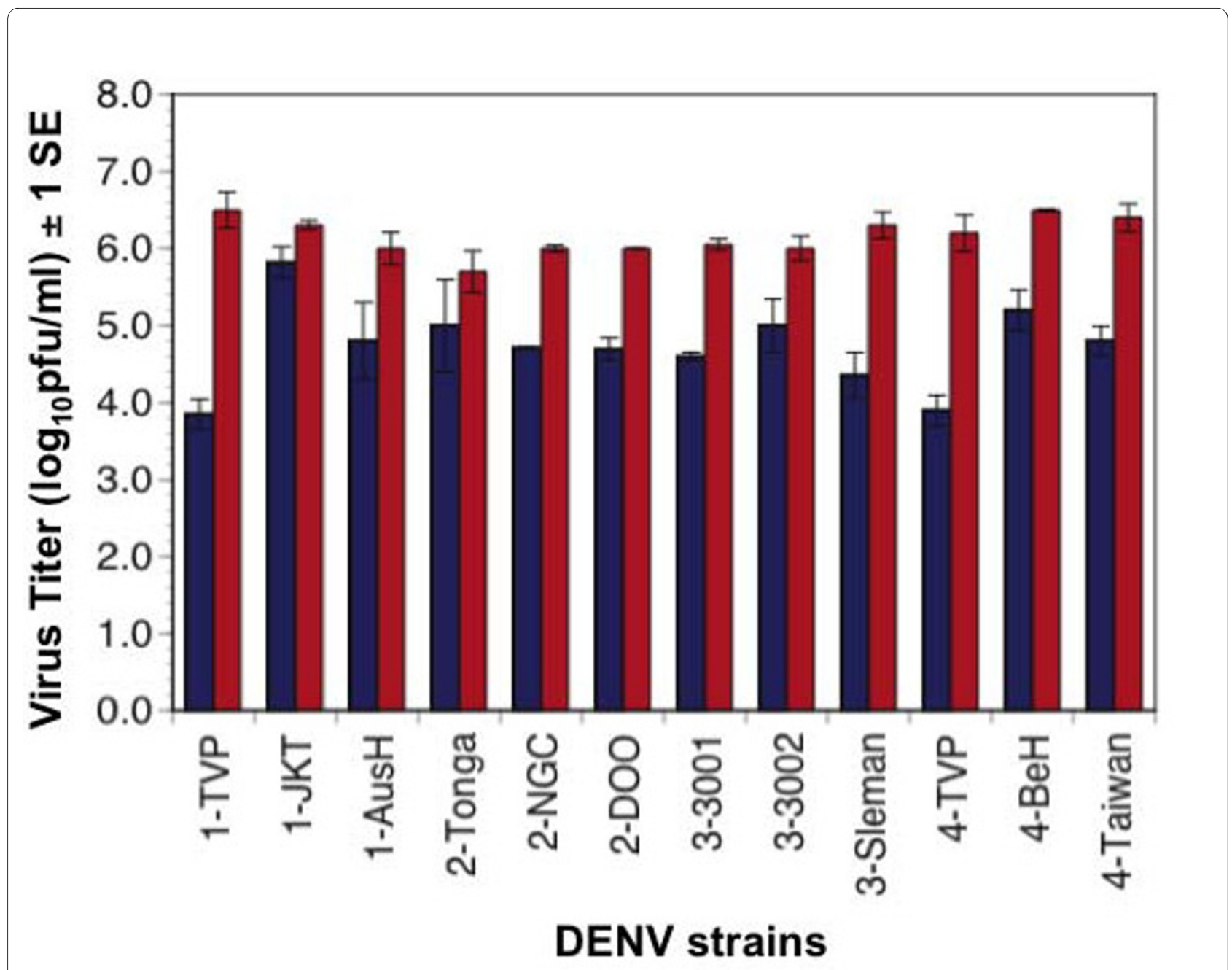

Figure 6 Titer of 12 strains of DENV five days post infection in S2 cells depleted of Dcr-2 (red bars) or control cells (blue bars).

lation of an antiviral response is indicative of active replication of DENV.

There was no evidence of change in titer of DENV between a first and second passage on S2 cells. However future studies to monitor adaptation after extensive serial passage in S2 cells are planned. Sessions et al. [33] reported that DENV-2 NGC attained a peak titer of 3.0 $\log _{10} \mathrm{pfu} / \mathrm{ml}$ in S2 derived D.Mel-2 cells without prior adaptation. Following serial passages for four months in D.Mel-2 cells, DENV-2 NGC titer increased to 5.0 $\log _{10} \mathrm{pfu} / \mathrm{ml}$. Consistent with these findings, in the current study peak titers of DENV in S2 cells infected at MOI 0.1 were approximately $3.0 \log _{10} \mathrm{pfu} / \mathrm{ml}$ [33]. However peak titers following infection at MOI 10 were at least an order of magnitude higher. Like other RNA viruses, DENV exists as a quasispecies [34-37], and it is possible that variants that were better able to infect S2 cells occurred in the larger virus population used to infect at MOI $10\left(7.0 \log _{10} \mathrm{pfu}\right)$ relative to MOI $0.1\left(5.0 \log _{10} \mathrm{pfu}\right)$. This hypothesis is supported by the finding that viruses that were taken from the MOI 10 infection and passaged again onto $\mathrm{S} 2$ cells achieved a similar titer to the S2 p1 MOI 10 infection, even though their founding population was only $3.2-4.4 \log _{10}$ pfu.

Using DENV adapted to S2 cells, Sessions et al. demonstrated the utility of these cells for investigation of dengue virus host factors (DVHF) [33]. They identified 116 DVHF using a genome-wide RNAi screen on D.Mel-2 cells. Findings from the current study indicate that S2 cells can also support replication of unadapted DENV, thereby offering additional opportunities to leverage the extraordinary depth of knowledge and plethora of tools in Drosophila genetics for the study of DENV [38].

The titer of each DENV strain in S2 cells was substantially lower than its titer in C6/36 cells, which are derived from Ae. albopictus, a natural DENV vector $[39,40]$. At 

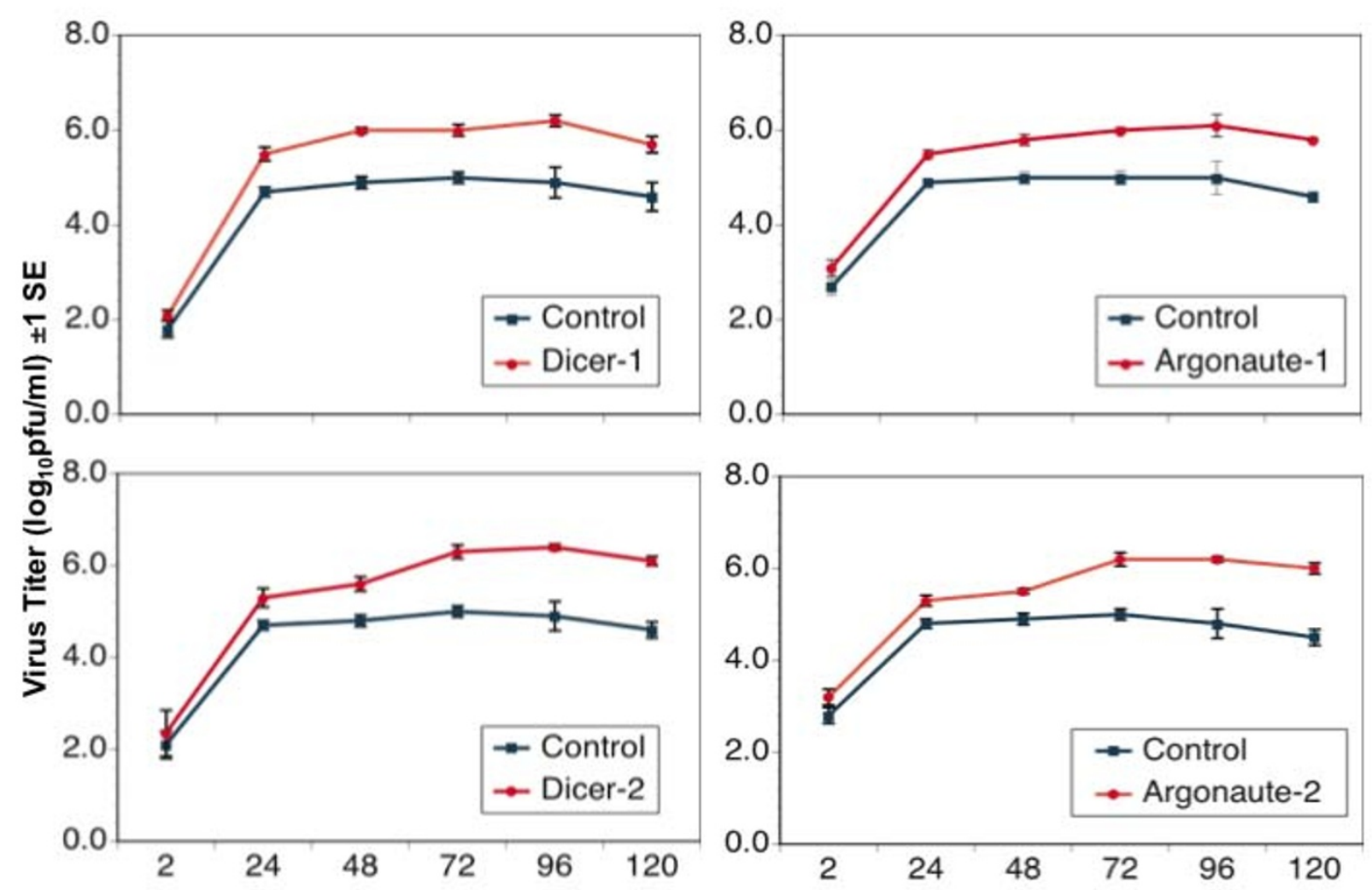

Hours post infection

Figure 7 Replication kinetics of DENV-2 Tonga in S2 cells depleted of specified components of the RNAi pathway.

first glance, this result seems to suggest S2 cells may not be a useful model to study DENV-vector interactions. However, it has been previously demonstrated that C6/36 cells exhibit a weak, and possibly incomplete, RNAi response [16,17], which may contribute to their ability to support high levels of DENV replication. In contrast, both live mosquitoes $[41,42]$ and S2 cells $[21,43]$ marshal a vigorous RNAi response to infection with flaviviruses and other RNA viruses that is capable of limiting viral replication [43-45]. Thus for some areas of study, particularly RNAi-virus interactions, S2 cells may be preferable to $\mathrm{C6/36}$ cells as an in vitro model.

In this study S2 cells infected with DENV-1, 2, 3 or 4 produced siRNAs targeting the DENV genome, as has been reported previously for a variety of viruses, including DENV, in multiple types of insect cells both in culture and in vivo [41,43]. In a notable exception to this rule, C6/ 36 cells failed to produce siRNAs when infected with WNV [16]. The production of anti-DENV siRNA provides confirmation that DENV is targeted by an active RNAi response in S2 cells. Further, a decrease in virus derived small RNAs was observed when Dcr-2 or Dcr-1 was knocked down prior to infection. This finding supports the conclusion that enhancement of DENV replication following knockdown of components of RNAi (discussed below) resulted from a relaxation of RNAi control. Although the current study was designed to detect only siRNAs complementary to the positive sense 3' UTR, it would be very useful in the future to characterize the entire suite of siRNAs produced in response to DENV infection.

In Drosophila, virus derived small RNAs can be generated by Dcr- 2 or Dcr-1 [11] and subsequently processed by Ago-1 or Ago-2-RISC (RNA Induced Silencing Complex) [46] (Figure 1). Knockdown of Dcr-2 enhanced the replication of each of 12 strains of DENV, and knockdown of Ago1, Ago-2 or Dcr-1 enhanced replication of the two DENV strains tested. None of the four knockdowns affected cell viability, supporting the conclusion that the observed augmentation of DENV replication was due to knockdown of the targeted enzymes rather than off-target effects. There was no difference in the impact 


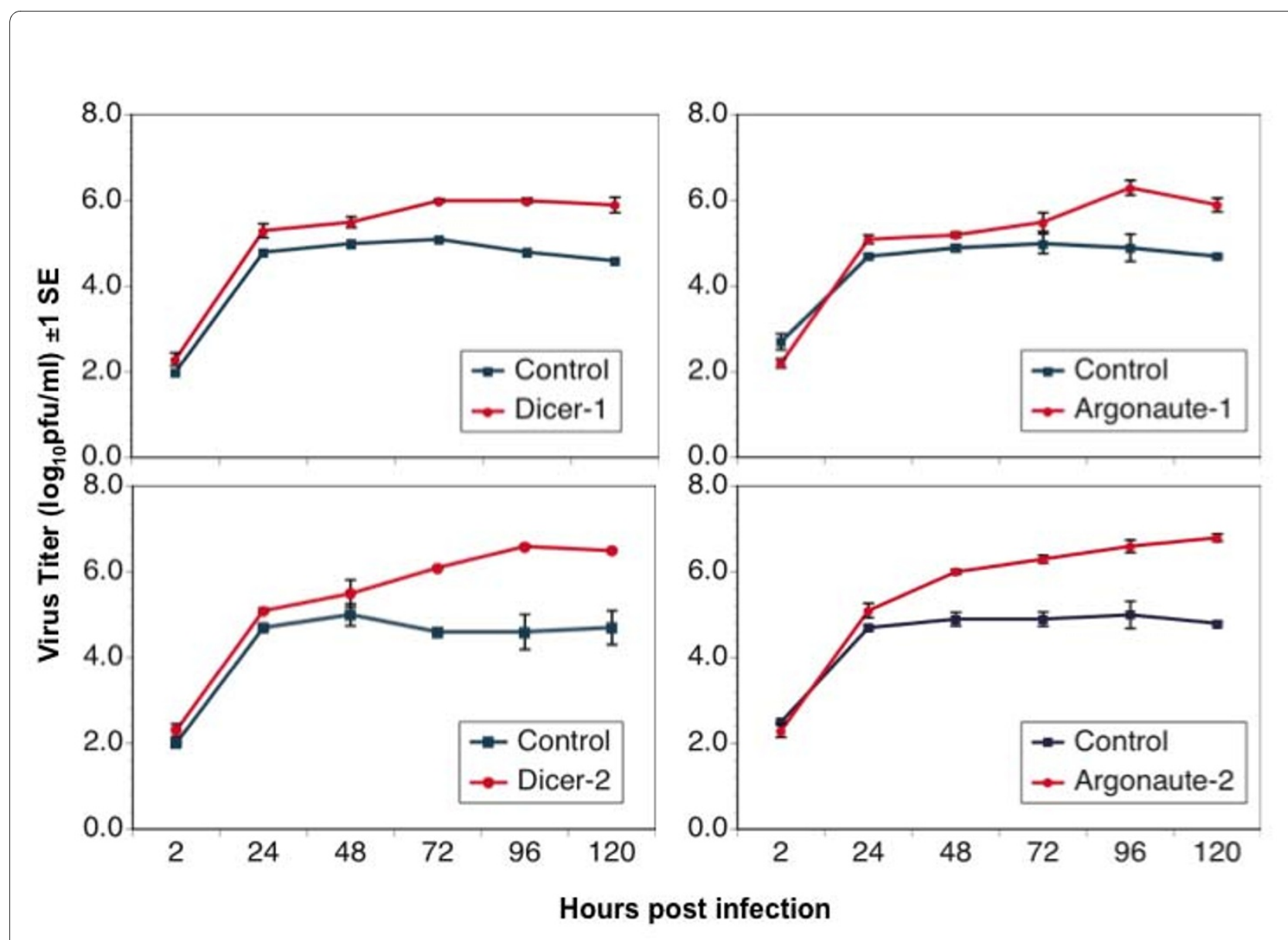

Figure 8 Replication kinetics of DENV-4 Taiwan in S2 cells depleted of specified components of the RNAi pathway.

of the four enzymes on DENV replication dynamics, and there was no difference among serotypes in their average response to the knockdown of Dcr-2. Intriguingly, strains within DENV-1 and DENV-4 serotypes showed significant variation in their response to Dcr-2 knockdown. These data suggest that DENV strains may vary in their sensitivity to RNAi, potentially contributing to differences in viral replication in the vector with downstream effects on transmission. Although the current study was not designed to draw inferences about response of specific DENV genotypes to RNAi or to contrast isolates associated with different grades of disease severity, the S2 system could be used to address these questions in the future.

The impact of Dcr-2 and Ago-2 knockdowns in this study are generally consistent with the results of SanchezVargas et al. [18], who found that knockdown of either enzyme in Ae. aegypti in vivo enhanced replication of DENV-2, although the impact of Ago-2 knockdown was delayed in time relative to Dcr-2. However our results in $\mathrm{S} 2$ cells differ from the finding of Chotkowski et al. that loss of Dcr-2 expression in S2 cells did not affect WNV replication [16]. This disparity may reflect methodological differences, particularly differences in expression of RNAi-pathway proteins between S2 cell lines, or differences between WNV and DENV in sensitivity to RNAi, and/or differences between the two viruses in their tendency to elicit RNAi.

Other studies have also revealed variation among viruses in their sensitivity to loss of Dcr-2 function. Drosophila carrying a homozygous null mutation for Dcr-2 were hypersusceptible to infection by Drosophila $\mathrm{C}$ virus (DCV) and cricket paralysis virus [47], and loss of function of Dcr-2 in Drosophila also resulted in increased infection by Flock House virus, DCV and Sindbis virus [48]. In contrast, homozygous knockout of Dcr-2 in Drosophila had no impact on susceptibility to Drosophila X virus (DXV) [49]. In the studies that detected no impact of Dcr-2 function on replication of WNV or DCV, respectively $[16,49]$, the authors suggested that synthesis of siRNA by Dcr-1 may counteract the effect of loss of Dcr-2. 
In the current study, knockdown of either Dcr-1 or Ago-1 enhanced DENV replication to a degree similar to each other and to Dcr-2 and Ago-2. These findings indicate that the proteins are functionally linked between the miRNA and siRNA braches of the RNAi pathway and thus impact viral replication. These findings are consistent with the report that Drosophila carrying a homozygous null mutation for Aubergine (an Ago-1 homolog) exhibit increased susceptibility to DXV infection [49] and support the idea that Dcr-1 and Ago-1 also regulate virus replication. Such regulation likely stems from the activity of Dcr-1 and Ago-1 in the siRNA branch of the RNAi pathway. Evidence of such activity includes the requirement of Dcr-1 for mRNA degradation [11], the observation of similar transcript profiles in cells depleted of Ago1 and Ago-2 [50], and the weak association of Ago- 1 with siRNAs in cells depleted of Ago-2 [46]. From this perspective, it would be particularly interesting in future studies to assess the impact of concurrent knockdown of Dcr-1 and Dcr-2 or Ago-1 and Ago-2 on the dynamics of DENV replication.

\section{Conclusion}

Our results indicate that RNA interference regulates DENV replication in Drosophila S2 cells, and that DENV strains, but not serotypes, vary in their sensitivity to such regulation. S2 cells offer a useful model for the study of DENV-RNAi interactions.

\footnotetext{
Abbreviations

RNAi: RNA interference; DENV: dengue virus; DENV-1-4: dengue virus serotypes 1-4; WNV: West Nile virus; DCV: Drosophila C virus; DXV: Drosophila X virus; Ago: Argonaute; Dcr: Dicer; siRNA: short interfering RNA; miRNA: microRNA; Spn: Spindle; pi: Post Infection; DIG: digoxigenin; UTR: untranslated region; bp: base pair; siRISC: RNA Induced Silencing Complex associated with siRNA; RISC: RNA Induced silencing complex; miRNP: miRNA associated Ribo Nucleoprotein Complex; miRISC: miRNA associated RISC; dsRNA: double stranded RNA; MOI: multiplicity of infection; PSF: Penicillin-Streptomycin-Fungizone ${ }^{\circ}$ MEM: Minimum Essential Media; hr: hour; df: degrees of freedom; p1: passage 1; p2: passage 2.
}

\section{Competing interests}

The authors declare that they have no competing interests.

\section{Authors' contributions}

Experiments were conceived by SM and KAH and performed by SM. Data was analyzed by SM and $\mathrm{KAH}$. The manuscript was written by SM and $\mathrm{KAH}$. All authors have read and approved the final manuscript.

\section{Acknowledgements}

We are grateful to Dr. Robert B. Tesh and the World Reference Center of Emerging Viruses and Arboviruses (UTMB), Dr. Stephen S. Whitehead (NIAID, NIH) and Dr. Aravinda de Silva (UNC) for providing us with virus isolates and antibodies. Funding for this project was provided by NSF-ADVANCE (SBE-123690), NIHNM-INBRE (P20RR016480-05), NIH R21 (1R21AI082399-01) and an NMSU minigrant (113462). We thank Mike Burnett and Erin E. Schirtzinger of the NMSU Biology Department for assistance with S2 cell culture and experiments.

\section{Author Details}

'Molecular Biology Program, New Mexico State University, Las Cruces, NM 88003, USA and 2Department of Biology, New Mexico State University, Las Cruces, NM 88003, USA
Received: 1 September 2009 Accepted: 27 April 2010

Published: 27 April 2010

\section{References}

1. Kyle JL, Harris E: Global spread and persistence of dengue. Annu Rev Microbiol 2008, 62:71-92

2. Gould EA, Solomon T: Pathogenic flaviviruses. Lancet 2008, 371(9611):500-509.

3. Halstead SB: Dengue virus-mosquito interactions. Annu Rev Entomol 2008, 53:273-291.

4. Keller T, Chen YL, Knox JE, Lim SP, Ma NL, Patel SJ, Sampath A, Wang QY, Yin Z, Vasudevan SG: Finding new medicines for flaviviraltargets. Novartis Found Symp 2006, 277:102-114. discussion 114-109, 251-103.

5. Whitehead SS, Blaney JE, Durbin AP, Murphy BR: Prospects for a dengue virus vaccine. Nat Rev Microbiol 2007, 5(7):518-528.

6. Stephenson JR: Developing vaccines against flavivirus diseases: past success, present hopes and future challenges. Novartis Found Symp 2006, 277:193-201.

7. Stein DA, Shi PY: Nucleic acid-based inhibition of flavivirus infections. Front Biosci 2008, 13:1385-1395.

8. Haasnoot PC, Cupac D, Berkhout B: Inhibition of virus replication by RNA interference. J Biomed Sci 2003, 10(6 Pt 1):607-616.

9. Valencia-Sanchez MA, Liu J, Hannon GJ, Parker R: Control of translation and mRNA degradation by miRNAs and siRNAs. Genes Dev 2006, 20(5):515-524.

10. Forstemann K, Horwich MD, Wee L, Tomari Y, Zamore PD: Drosophila microRNAs are sorted into functionally distinct argonaute complexes after production by dicer-1. Cell 2007, 130(2):287-297.

11. Lee YS, Nakahara K, Pham JW, Kim K, He Z, Sontheimer EJ, Carthew RW: Distinct roles for Drosophila Dicer-1 and Dicer-2 in the siRNA/miRNA silencing pathways. Cell 2004, 117(1):69-81.

12. Okamura K, Lai EC: Endogenous small interfering RNAs in animals. Nat Rev Mol Cell Biol 2008, 9(9):673-678.

13. Meyer WJ, Schreiber S, Guo Y, Volkmann T, Welte MA, Muller HA: Overlapping functions of argonaute proteins in patterning and morphogenesis of Drosophila embryos. PLoS Genet 2006, 2(8):e134.

14. Kumar P, Lee SK, Shankar P, Manjunath N: A single siRNA suppresses fatal encephalitis induced by two different flaviviruses. PLOS Med 2006, 3(4):e96.

15. Franz AW, Sanchez-Vargas I, Adelman ZN, Blair CD, Beaty BJ, James AA, Olson KE: Engineering RNA interference-based resistance to dengue virus type 2 in genetically modified Aedes aegypti. Proc Natl Acad SCi USA 2006, 103(11):4198-4203.

16. Chotkowski HL, Ciota AT, Jia Y, Puig-Basagoiti F, Kramer LD, Shi PY, Glaser $\mathrm{RL}$ : West Nile virus infection of Drosophila melanogaster induces a protective RNAi response. Virology 2008, 377(1):197-206.

17. Caplen NJ, Zheng Z, Falgout B, Morgan RA: Inhibition of viral gene expression and replication in mosquito cells by dsRNA-triggered RNA interference. Mol Ther 2002, 6(2):243-251.

18. Sanchez-Vargas I, Scott JC, Poole-Smith BK, Franz AW, Barbosa-Solomieu V, Wilusz J, Olson KE, Blair CD: Dengue virus type 2 infections of Aedes aegypti are modulated by the mosquito's RNA interference pathway. PLOS Pathog 2009, 5(2):e1000299.

19. Rogers SL, Rogers GC: Culture of Drosophila S2 cells and their use for RNAi-mediated loss-of-function studies and immunofluorescence microscopy. Nat Protoc 2008, 3(4):606-611.

20. Li WX, Li H, Lu R, Li F, Dus M, Atkinson P, Brydon EW, Johnson KL, GarciaSastre A, Ball LA, et al.: Interferon antagonist proteins of influenza and vaccinia viruses are suppressors of RNA silencing. Proc Natl Acad Sci USA 2004, 101(5):1350-1355.

21. Caplen NJ, Fleenor J, Fire A, Morgan RA: dsRNA-mediated gene silencing in cultured Drosophila cells: a tissue culture model for the analysis of RNA interference. Gene 2000, 252(1-2):95-105

22. Schneider I: Cell lines derived from late embryonic stages of Drosophila melanogaster. J Embryol Exp Morphol 1972, 27:353-365.

23. Singh KR, Paul SD: Isolation of Dengue viruses in Aedes albopictus cell cultures. Bull World Health Organ 1969, 40(6):982-983.

24. Hanley KA, Nelson JT, Schirtzinger EE, Whitehead SS, Hanson CT: Superior infectivity for mosquito vectors contributes to competitive displacement among strains of dengue virus. BMCECO/ 2008, 8:1. 
25. Pepin KM, Lambeth K, Hanley KA: Asymmetric competitive suppression between strains of dengue virus. BMC Microbio/ 2008, 8:28.

26. Hanley KA, Goddard LB, Gilmore LE, Scott TW, Speicher J, Murphy BR, Pletnev AG: Infectivity of West Nile/dengue chimeric viruses for West Nile and dengue mosquito vectors. Vector Borne Zoonotic Dis 2005 , 5(1):1-10.

27. Hanley KA, Lee JJ, Blaney JE Jr, Murphy BR, Whitehead SS: Paired chargeto-alanine mutagenesis of dengue virus type 4 NS5 generates mutants with temperature-sensitive, host range, and mouse attenuation phenotypes. J Virol 2002, 76(2):525-531.

28. Pepin KM, Hanley KA: Density-dependent competitive suppression of sylvatic dengue virus by endemic dengue virus in cultured mosquito cells. Vector Borne Zoonotic Dis 2008, 8(6):821-8.

29. Troyer JM, Hanley KA, Whitehead SS, Strickman D, Karron RA, Durbin AP, Murphy BR: A live attenuated recombinant dengue- 4 virus vaccine candidate with restricted capacity for dissemination in mosquitoes and lack of transmission from vaccinees to mosquitoes. Am J Trop Med Hyg 2001, 65(5):414-419.

30. Brackney DE, Beane JE, Ebel GD: RNAi targeting of West Nile virus in mosquito midguts promotes virus diversification. PLoS Pathog 2009, 5(7):e1000502.

31. Kao LR, Megraw TL: RNAi in cultured Drosophila cells. Methods Mol Biol 2004, 247:443-457.

32. St-Pierre P, Hassen IF, Thompson D, Perreault JP: Characterization of the siRNAs associated with peach latent mosaic viroid infection. Virology 2009, 383(2):178-182.

33. Sessions OM, Barrows NJ, Souza-Neto JA, Robinson TJ, Hershey CL, Rodgers MA, Ramirez JL, Dimopoulos G, Yang PL, Pearson JL, et al: Discovery of insect and human dengue virus host factors. Nature 2009, 458(7241):1047-1050.

34. Wang WK, Lin SR, Lee CM, King CC, Chang SC: Dengue type 3 virus in plasma is a population of closely related genomes: quasispecies. $\mathrm{J}$ Virol 2002, 76(9):4662-4665

35. Lin SR, Hsieh SC, Yueh YY, Lin TH, Chao DY, Chen WJ, King CC, Wang WK: Study of sequence variation of dengue type 3 virus in naturally infected mosquitoes and human hosts: implications for transmission and evolution. J Virol 2004, 78(22):12717-12721.

36. Wang WK, Sung TL, Lee CN, Lin TY, King CC: Sequence diversity of the capsid gene and the nonstructural gene NS2B of dengue- 3 virus in vivo. Virology 2002, 303(1):181-191.

37. Chao DY, King CC, Wang WK, Chen WJ, Wu HL, Chang GJ: Strategically examining the full-genome of dengue virus type 3 in clinical isolates reveals its mutation spectra. Virol $J$ 2005, 2:72.

38. Huszar T, Imler JL: Drosophila viruses and the study of antiviral hostdefense. Adv Virus Res 2008, 72:227-265.

39. Vasilakis NWS: Chapter 1 The History and Evolution of Human Dengue Emergence. Adv Virus Res 2008, 72:1-76.

40. Gubler DJ: Dengue and dengue hemorrhagic fever. Clin Microbiol Rev 1998, 11(3):480-496.

41. Sanchez-Vargas I, Travanty EA, Keene KM, Franz AW, Beaty BJ, Blair CD, Olson KE: RNA interference, arthropod-borne viruses, and mosquitoes. Virus Res 2004, 102(1):65-74.

42. Keene KM, Foy BD, Sanchez-Vargas I, Beaty BJ, Blair CD, Olson KE: RNA interference acts as a natural antiviral response to O'nyong-nyong virus (Alphavirus; Togaviridae) infection of Anopheles gambiae. Proc Natl Acad Sci USA 2004, 101(49):17240-17245.

43. Li H, Li WX, Ding SW: Induction and suppression of RNA silencing by an animal virus. Science 2002, 296(5571):1319-1321.

44. Campbell CL, Keene KM, Brackney DE, Olson KE, Blair CD, Wilusz J, Foy BD: Aedes aegypti uses RNA interference in defense against Sindbis virus infection. BMC Microbiol 2008, 8:47.

45. Wang XH, Aliyari R, Li WX, Li HW, Kim K, Carthew R, Atkinson P, Ding SW: RNA interference directs innate immunity against viruses in adult Drosophila. Science 2006, 312(5772):452-454.

46. Tomari Y, Du T, Zamore PD: Sorting of Drosophila small silencing RNAs. Cell 2007, 130(2):299-308.

47. van Rij RP, Saleh MC, Berry B, Foo C, Houk A, Antoniewski C, Andino R: The RNA silencing endonuclease Argonaute 2 mediates specific antiviral immunity in Drosophila melanogaster. Genes Dev 2006, 20(21):2985-2995.
48. Galiana-Arnoux D, Dostert C, Schneemann A, Hoffmann JA, Imler JL: Essential function in vivo for Dicer-2 in host defense against RNA viruses in Drosophila. Nat Immunol 2006, 7(6):590-597.

49. Zambon RA, Vakharia VN, Wu LP: RNAi is an antiviral immune response against a dsRNA virus in Drosophila melanogaster. Cell Microbiol 2006, 8(5):880-889.

50. Rehwinkel J, Natalin P, Stark A, Brennecke J, Cohen SM, Izaurralde E: Genome-wide analysis of mRNAs regulated by Drosha and Argonaute proteins in Drosophila melanogaster. Mol Cell Biol 2006, 26(8):2965-2975.

51. Miyoshi K, Tsukumo H, Nagami T, Siomi H, Siomi MC: Slicer function of Drosophila Argonautes and its involvement in RISC formation. Genes Dev 2005, 19(23):2837-2848

52. Liu Q, Rand TA, Kalidas S, Du F, Kim HE, Smith DP, Wang X: R2D2, a bridge between the initiation and effector steps of the Drosophila RNAi pathway. Science 2003, 301(5641):1921-1925.

53. Kennerdell $J R$, Yamaguchi $S$, Carthew RW: RNAi is activated during Drosophila oocyte maturation in a manner dependent on aubergine and spindle-E. Genes Dev 2002, 16(15):1884-1889.

54. Megosh HB, Cox DN, Campbell C, Lin H: The role of PIWI and the miRNA machinery in Drosophila germline determination. Curr Biol 2006, 16(19):1884-1894.

55. Okamura K, Ishizuka A, Siomi H, Siomi MC: Distinct roles for Argonaute proteins in small RNA-directed RNA cleavage pathways. Genes Dev 2004, 18(14):1655-1666

56. Jiang F, Ye X, Liu X, Fincher L, McKearin D, Liu Q: Dicer-1 and R3D1-L catalyze microRNA maturation in Drosophila. Genes Dev 2005, 19(14):1674-1679.

57. Meister G, Tuschl T: Mechanisms of gene silencing by double-stranded RNA. Nature 2004, 431(7006):343-349.

doi: $10.1186 / 1471-2180-10-127$

Cite this article as: Mukherjee and Hanley, RNA interference modulates replication of dengue virus in Drosophila melanogaster cells BMC Microbiology 2010, 10:127

\section{Submit your next manuscript to BioMed Central and take full advantage of:}

- Convenient online submission

- Thorough peer review

- No space constraints or color figure charges

- Immediate publication on acceptance

- Inclusion in PubMed, CAS, Scopus and Google Scholar

- Research which is freely available for redistribution

Submit your manuscript at www.biomedcentral.com/submit
C) Biomed Central 